\title{
Maternal awareness and neonatal outcome after ketamine induc- tion of anaesthesia for Caesarean section
}

Ketamine was used as the sole anaesthetic during the induction10-delivery interval in 20 full-term patients undergoing elective Caesarean section. The intravenous administration of ketamine $1.5 \mathrm{mg} \cdot \mathrm{kg}^{-1}$ was followed by succinylcholine $1.5 \mathrm{mg} \cdot \mathrm{kg}^{-1}$ and tracheal intubation. The mother's lungs were then ventilated using 100 per cent oxygen until the baby was delivered. Intraoperative maternal awareness was assessed by the isolated forearm technique. The Apgar scores of the newborn at one and five minutes, as well as their umbilical vein blood gases were also evaluated and correlated with the induction-to-delivery $(I-D)$ and the uterine incision-to-delivery $(U-D)$ intervals. In 13 patients (Group A) the I-D interval was $<10$ min and $U-D$ interval $<90 \mathrm{sec}$, while in seven (Group $B$ ) the $I-D$ interval was $\geq 10$ min and the $U-D$ interval $\geq 90 \mathrm{sec}$. The isolated arm test was negative in all patients having an I-D interval $<10 \mathrm{~min}$, and was positive in three patients when the $I-D$ interval exceeded ten minutes. The newborns of group $A$ showed higher Apgar scores at one minute, as well as higher umbilical vein $\mathrm{PO}_{2}$ than was achieved in Group B. It was concluded that the technique used was not associated with maternal awareness or neonatal depression, provided that the $1-D$ interval was $<10$ min and the $U-D$ interval was $<90$ sec.

Lors de 20 césariennes électives chez des patientes à terme, nous n'avons utilisé que de la kétamine comme anesthésique jusqu' au moment de la naissance. Après l'injection intraveineuse de 1,5 $\mathrm{mg} \cdot \mathrm{kg}^{-1}$ de kétamine et de $1,5 \mathrm{mg} \cdot \mathrm{kg}^{-1}$ de succinylcholine, nous intubions la trachée el ventilions les poumons avec de

\section{Key words}

ANAESTHESIA: obstetrical, Caesarean section;

ANAESTHETICS, INTRAVENOUS: ketamine; COMPLICATIONS: awareness, fetal depression.

From the Department of Anesthesiology, American University of Beirut, Beirut, Lebanon.

Address correspondence 1o: Dr. A. Baraka, Department of Anesthesiology, American University of Beirut, 850 Third Avenue, 18th Floor, New York, NY 10022 U.S.A. l'axygène jusqu'à la naissance. La présence d' un garrot isolant l'avant-bras du myorelaxant permettait de détecter un éventuel éveil intra-opératoire chez la mère. Nous mesurions l'Apgar à une et cinq minules de même que les gaz veineux ombilicaux, le tous, en corrélation avec l'intervalle entre l'induction anesthé. sique et la naissance $(A-N)$ et celui entre l'incision utérine et la naissance $(U-N)$. Chez 13 patientes (Groupe A), ces intervalles étaient respectivement inférieurs à $10 \mathrm{~min}$ et à $90 \mathrm{sec}$ tandis que chez les autres (Groupe B), ils étaient d'au moins 10 min et d' au moins $90 \mathrm{sec}$. Aucune des patientes dont l'intervalle $A-N$ était inférieur à $10 \mathrm{~min}$, ne manifesta de signe d'éveil, contrairemen à trois patientes du Groupe B. Les nouveaux-nés du Groupe A avaient un meilleur Apgar à une minute et une $\mathrm{PO}_{2}$ de la veine ombilicale plus élevée que ceux du Groupe B. Il semble donc que cette technique ne s'accompagne pas d'éveil maternel ni de dépression néonatale si l'intervalle $A-N$ est de moins de $10 \mathrm{~min}$ et l'intervalle $U-N$ de moins de $90 \mathrm{sec}$.

Ketamine has been recommended as an alternative to thiopentone for induction of general anaesthesia in patients undergoing elective Caesarean section. Intraoperative maternal awareness is significantly lower after ketamine induction than after thiopentone. ${ }^{1,2}$ The present report investigated the use of ketamine as the sole anaesthetic until the newborn was delivered in patients undergoing elective Caesarean section. The study reports the incidence of maternal intraoperative awareness. It also reports the Apgar scores and the umbilical vein blood gas analysis of newborns, and evaluates the relationship of these variables to the induction-to-delivery (I-D) and the uterine incision-to-delivery (U-D) intervals.

\section{Methods}

Twenty full-term patients undergoing elective Caesarean section were investigated. Their ages ranged between 19-38 yr, and their body weight between $52-88 \mathrm{~kg}$. Patients with a history of hypertension and preeclampsia were excluded, as were patients with signs of fetal distress or abnormality. The investigation was approved by the 
Institution Research Committee and informed consent was obtained.

All patients were premedicated with glycopyrrolate 0.2 $\mathrm{mg}$ IM. In the operating room, the patient was positioned on the operating table in a left lateral tilt of approximately $15^{\circ}$. An IV infusion of lactated Ringer's solution was started on the dorsum of the left hand. All patients then received preoxygenation for three to five minutes with 100 per cent oxygen via a facemask. The patients were prepared and draped during preoxygenation and before induction of anaesthesia to reduce the I-D interval. A rapid sequence induction of anaesthesia was used in all patients. Anaesthesia was achieved with ketamine 1.5 $\mathrm{mg} \cdot \mathrm{kg}^{-1}$. When the patient lost consciousness, succinylcholine $1.5 \mathrm{mg} \cdot \mathrm{kg}^{-1}$ was injected and the trachea was intubated.

Following intubation, the lungs were ventilated during the I-D interval with 100 per cent oxygen without any inhalational anaesthetic supplementation. Following recovery from succinylcholine, neuromuscular blockade was maintained with alcuronium $0.25 \mathrm{mg} \cdot \mathrm{kg}^{-1}$. The EKG was monitored throughout surgery. Arterial blood gas analysis prior to delivery showed $\mathrm{PO}_{2}$ ranging between $427-477 \mathrm{mmHg}$ and $\mathrm{PCO}_{2}$ between $34-41$ $\mathrm{mmHg}$. Systolic arterial blood pressure and heart rate were measured prior to induction of anaesthesia, after ketamine injection and prior to administration of succinylcholine, one minute post-intubation and prior to delivery.

Awareness during the I-D interval was detected by using the isolated forearm technique. ${ }^{2} \mathrm{~A}$ pneumatic tourniquet was wrapped around the right arm before induction of anaesthesia. After unconsciousness was achieved with ketamine and before succinylcholine was injected, the tourniquet was inflated to $250 \mathrm{mmHg}$ in order to maintain power in the isolated arm.

Following tracheal intubation, the patient's right hand was clasped by the anaesthetist and the patient was asked to squeeze her hand. The test was considered positive if the patient responded to the command. The test was repeated at one minute intervals until the baby was delivered.

Immediately after delivery, a blood sample was taken from a doubly clamped segment of the umbilical cord for umbilical vein blood gas analysis. Apgar scores of the newborns were assessed at one and five minutes and were correlated with the I-D and the U-D intervals. After delivery, anaesthesia was maintained with nitrous oxide: oxygen (2:1), supplemented with fentanyl $2 \mu \mathrm{g} \cdot \mathrm{kg}^{-1}$. At the end of surgery, neuromuscular blockade was reversed with a mixture of neostigmine $0.05 \mathrm{mg} \cdot \mathrm{kg}^{-1}$ and atropine $0.02 \mathrm{mg} \cdot \mathrm{kg}^{-1}$. Following recovery from anaesthesia and on the following day, the mothers were interviewed to assess any recall or hallucinations.
All data other than frequency were expressed as mean $\pm \mathrm{SD}$. The frequency data were compared using Chisquare analysis, analysis of variance was used to compare blood pressure and heart rate changes, while Student's t test was used to compare the other data. $P<0.05$ was considered significant.

\section{Results}

\section{$I-D$ and $U-D$ intervals}

The I-D intervals ranged between $3-17 \mathrm{~min}$ and the U-D intervals ranged between $30-210 \mathrm{sec}$. In 13 patients, the I-D interval was $<10$ minutes and the U-D interval $<90$ seconds. In seven patients, the $1-D$ interval was $\geq 10$ minutes and the $U-D$ interval $\geq 90$ seconds.

\section{Awareness}

The isolated forearm test was negative in the 13 patients having an $I-D$ interval $<10$ minutes, and was positive in three of seven patients when the I-D interval exceeded ten minutes. However, no postoperative recall or hallucinations were reported by any patient.

\section{Blood pressure and heart rate changes}

The mean systolic blood pressure and heart rate were moderately increased following ketamine administration. After tracheal intubation, there was a further significant increase of blood pressure (Table I).

\section{Newborns}

The newborns were classified into two groups according to the I-D and U-D intervals. Group A consisted of 13 newborns who were delivered after $1-D$ intervals $<10$ min and U-D intervals $<90 \mathrm{sec}$. Group B consisted of seven newborns who were delivered after I-D intervals $\geq 10 \mathrm{~min}$ and $U-D$ intervals $\geq 90 \mathrm{sec}$. As shown in Table II, the Apgar scores at one minute and the umbilical vein $\mathrm{PO}_{2}$ were significantly higher in Group $\mathrm{A}$ than in Group B.

However, there was no significant difference in umbilical vein $\mathrm{PCO}_{2}, \mathrm{pH}$, or base deficit between the two groups.

\section{Discussion}

The present report shows that ketamine in a dose of 1.5 $\mathrm{mg} \cdot \mathrm{kg}^{-1}$ may be used as the sole anaesthetic during the I-D interval in patients undergoing Caesarean section. Ketamine decreases the likelihood of maternal intraoperative awareness as detected by the isolated forearm technique; $;^{1,2}$ no patient revealed intraoperative awareness when the 1-D interval was less than ten minutes. However, three of seven patients revealed awareness when the $I-D$ interval exceeded ten minutes. This may be 
TABLE I Mean systolic blood pressure and heart rate of the mother: control, following injection of ketamine, one minule after intubation, and prior to delivery

\begin{tabular}{lclll}
\hline & Control & Ketamine & Post-intubation & Before delivery \\
\hline Systolic BP $(\mathrm{mmHg})$ & $114 \pm 9.0$ & $127 \pm 14.0^{*}$ & $148 \pm 19.0 \dagger$ & $138 \pm 17.0 \dagger$ \\
Heart rate $\cdot \mathrm{min}^{-1}$ & $92 \pm 12$ & $103 \pm 13.0^{*}$ & $106 \pm 14^{*}$ & $109 \pm 10^{*}$ \\
\hline
\end{tabular}

* Significant difference compared with control values.

†Significant differences compared with both the control and post-ketamine values.

attributed to the rapid redistribution of ketamine; redistribution half-life averages $4.68 \mathrm{~min}^{3}$ No postoperative recall or hallucinations were reported by any of the patients, suggesting that the incidence of hallucinations and other unpleasant emergence reactions associated with ketamine may be low in the obstetrical patient. ${ }^{4,5}$

In all patients, ketamine administration was followed by increases in systolic blood pressure and heart rate. This can be attributed to the sympathomimetic effect of ketamine which has been shown in man to increase the blood levels of both epinephrine and norepinephrine. ${ }^{6}$ Despite these sympathomimetic effects, experimental studies in the pregnant ewe have shown that ketamine increases uterine blood flow and does not produce deleterious effects on fetal cardiovascular or acid-base status. ${ }^{7}$ Also, ketamine-oxygen anaesthesia does not cause further deterioration in blood gases or in cerebral and myocardial blood flow of the acidotic fetal lamb. ${ }^{8}$ These reports suggest that uterine and feto-placental perfusion are well maintained following ketamine anaesthesia.

The present investigation has shown that all newborns scored $\geq 7$ when the I-D interval was less than ten minutes, and the U-D interval was less than $90 \mathrm{sec}$.

However, prolongation of the I-D interval beyond ten minutes and the U-D interval to more than $90 \mathrm{sec}$ was followed by transient neonatal depression, associated with lower umbilical vein $\mathrm{PO}_{2}$. Our data suggest that both prolonged $\mathrm{I}-\mathrm{D}$ and $\mathrm{U}-\mathrm{D}$ intervals are associated with

TABLE II Neonatal Apgar scores and umbilical vein blood gas analysis. Apgar scores at one minute and umbilical vein $\mathrm{PO}_{2}$ were significantly higher in Group A than in Group B

\begin{tabular}{lcl}
\hline & $\begin{array}{c}\text { Group A } \\
(n=I 3)\end{array}$ & $\begin{array}{l}\text { Group B } \\
(n=7)\end{array}$ \\
\hline $\begin{array}{l}\text { Apgar scores } \geq 7 \\
I \mathrm{~min}\end{array}$ & \\
$5 \mathrm{~min}$ & 13 & 3 \\
& 13 & 6 \\
Umbilical vein blood gases afier delivery & \\
$\mathrm{PO}_{2} \mathrm{mmHg}$ & $28.0 \pm 5.9$ & $22.7 \pm 4.8$ \\
$\mathrm{PCO}_{2} \mathrm{mmHg}$ & $50.2 \pm 4.8$ & $53.9 \pm 5.5$ \\
$\mathrm{pH}$ & $7.30 \pm 0.03$ & $7.28 \pm 0.05$ \\
Base deficit meq $\cdot \mathrm{L}^{-1}$ & $-2.3 \pm 1.2$ & $-2.4 \pm 2.1$ \\
\hline
\end{tabular}

neonatal depression; the relative contribution of each remains uncertain, since all the newborns who were delivered after an I-D interval $>10$ minutes also had an U-D interval $>90 \mathrm{sec}$. Crawford et al. ${ }^{9}$ suggested that the most crucial factor determining the clinical and biochemical condition of the neonate delivered by elective Caesarean section under general anaesthesia, may not be the I-D interval but the $U-D$ interval. Prolonged uterine manipulation may adversely affect uteroplacental and umbilical cord circulation. ${ }^{10}$

The use of ketamine as the sole anaesthetic during the I-D interval provides maternal haemodynamic stability, and hence may be advantageous in hypovolaemic parturients. ${ }^{10}$ Also, it permits ventilation of the lungs with 100 per cent oxygen without inhalational anaesthetic supplementation until the newborn is delivered.

Although using 100 per cent oxygen instead of 50 per cent $\mathrm{N}_{2} \mathrm{O}: \mathrm{O}_{2}$ results in a nonsignificant change of umbilical vein $\mathrm{PO}_{2}$ and neonatal outcome in patients undergoing elective Caesarean section, ${ }^{2,12}$ the benefit may be greater in a fetus suffering from intrauterine asphyxia. ${ }^{13}$

In conclusion, the present report shows that ketamine $1.5 \mathrm{mg} \cdot \mathrm{kg}^{-1}$ can be used as the sole anaesthetic during the I-D interval in patients undergoing Caesarean section. The mother's lungs were ventilated with 100 per cent oxygen until the newborn was delivered. The technique was not associated with maternal intraoperative awareness or neonatal depression, provided $1-D$ interval was $<10$ minutes and the U-D interval was $<90 \mathrm{sec}$.

\section{References}

I Schultetus RR, Hill CR, Dharmraj CM, Banner TE, Berman LS. Wakefulness during Cesarean section after anesthetic induction with ketamine, thiopental, or ketamine and thiopental combined. Anesth Analg 1986; 65: 723-8.

2 Baraka A, Louis F, Noueihed R, Diab M, Dabbous A, Sibaii $A$. Awareness following different techniques of general anaesthesia for Caesarean section. $\mathrm{Br} J$ Anaesth 1989; 62: 645-8.

3 Domino EF, Domino SE, Smith RE et al. Ketamine kinetics in unmedicated and diazepam-premedicated subjects. Clin Pharmacol Ther 1984, 36: 645-53. 
4 Meer FM, Downing JW, Coleman AJ. An intravenous method of anaesthesia for Caesarean section. Part D: Ketamine. Br J Anaesth 1973, 45: 191-6.

5 White PF, Way WL, Trevor AJ, Ketamine - its pharmacology and therapeutic use. Anesthesiology 1982; 56: 119-38.

6 Baraka A, Harrison T, Kachachi T. Catecholamine levels after ketamine anesthesia in man. Anesth Analg 1973; 52: $198-200$.

7 Levinson G, Shnider SM, Gildea JE, De Lorimer $A A$. Maternal and foetal cardiovascular and acid-base changes during ketamine anaesthesia in pregnant ewes. $\mathrm{Br}$ J Anasth 1973; 45: 1111-5.

8 Swartz J, Cumming M, Biehl D. The effect of ketamine anaesthesia on the acidotic fetal lamb. Can J Anaesth 1987; 34: 233-7.

9 Crawford JS, James FM, Crawley $M$. A further study of general anaesthesia for Caesarean section. $\mathrm{Br} J$ Anaesth 1976; 48: 66I-7

10 Datta S, Ostheimer GW, Weiss JB, Brown WU, Alper $M H$. Neonatal effect of prolonged anesthetic induction for Cesarean section. Obstet Gynecol 1981; 58: 331-5.

11 Reich $D L$, Silvay $G$. Ketamine: an update on the first twenty-five years of clinical experience. Can J Anaesth 1989; 36: 186-97.

12 Baraka A. Correlation between maternal and fetal $\mathrm{PO}_{2}$ and $\mathrm{PCO}_{2}$ during Caesarean section. $\mathrm{Br} \mathrm{J}$ Anaesth 1970; 42: 434-8.

13 Bogad DG, Rosen M, Rees GAD. Maximum $\mathrm{FlO}_{2}$ during Caesarean section. Br J Anaesth 1988; 61: 255-62. 